\title{
Strategi Inovasi Pelayanan Kesehatan Pada Rumah Sakit Umum Daerah Kota Kendari
}

\author{
Fatkhul Manan ${ }^{1}$; Muh. Nasir ${ }^{2}$; Saidin ${ }^{3}$ \\ ${ }^{123}$ Universitas Halu Oleo, fatkhulmanan24@gmail.com
}

\begin{abstract}
Abstrak
Penelitian ini bertujuan untuk mengetahui Strategi Inovasi Pelayanan Kesehatan pada Rumah Sakit Umum Daerah Kota Kendari. Metode yang dilakukan dalam penelitian ini berupa penelitian deskriptif kualitatif dengan pengumpulan data melalui observasi, wawancara, dan dokumentasi. Penetuan informan dalam penelitian ini dilakukan dengan cara purposive sampling. Sedangkan teknik analisis data yang menggunakan model analisis deskriptif kualitatif. Hasil penelitian ini menunjukan bahwa strategi inovasi pelayanan kesehatan pada RSUD Kota Kendari berupa inovasi sistem informasi rujukan berbasis aplikasi web mengenai ketersediaan Ruang Rawat Inap atau yang dikenal dengan program inovasi Sistem Ketersediaan Kamar Rujukan Pasien (SEKAR) dengan sistem informasi layanan ini seluruh Puskesmas yang ada di Kota Kendari dapat memanfaatkan Informasi ini untuk memberikan pelayanan rujukan yang maksimal kepada masyarakat Kota Kendari khususnya bahkan masyarakat Sulawesi Tenggara pada umumnya dengan tujuan meminimalisir keluhan masyarakat tentang ketidakpastian ketersediaan kamar. Dengan adanya informasi ini, penanganan lebih cepat dilakukan sehingga dapat mencegah kematian karena keterlambatan akses pelayanan. Dalam penerapan inovasi ini pihak manajemen RSUD Kota Kendari masih menghadapi beberapa kendala diantaranya kurangnya sosialisasi dan publikasi mengenai layanan kesehatan ini, pemutahiran data pasien pada setiap kamar rawat menjadi kendala. Selain itu anggaran sebagai pemenuhan ketersedian sarana penunjang seperti komputer masih terbatas.
\end{abstract}

\section{Kata kunci : Inovasi, Kesehatan Pelayanan, Strategi}

\begin{abstract}
This study aims to determine the Health Service Innovation Strategy at the Kendari City General Hospital. The method used in this research is a qualitative descriptive study by collecting data through observation, interviews, and documentation.Determination of informants in this study was conducted by purposive sampling. While the data analysis technique uses a qualitative descriptive analysis model. The results of this study indicate that the health service innovation strategy at Kendari City Hospital is a web applicationbased referral information system innovation regarding the availability of Inpatient Rooms or known as the Innovation System for Patient Referral Room Availability Systems (SEKAR) with this service information system for all Puskesmas in Kendari City can utilize this information to provide maximum referral services to the people of Kendari City in particular even the people of Southeast Sulawesi in general with the aim of minimizing public complaints about the uncertainty of room availability. With this information, handling is faster so that it can prevent deaths due to delayed access to services. In the application of this innovation, the management of Kendari City Hospital still faces several obstacles including the lack of socialization and publication about this health service, updating patient data in each hospital room becomes an obstacle. In addition, the budget as a fulfillment of the availability of supporting facilities such as computers is still limited.
\end{abstract}

Keywords : Health, Innovation, Services, Strategies 


\section{Pendahuluan}

Menurut Kumorotomo (2013:6-7) ada beberapa hal yang dapat dikemukakan untuk menjelaskan mengapa selama ini banyak kebijakan, program dan pelayanan publik kurang responsif terhadap aspirasi masyarakat sehingga kurang mendapat dukungan secara luas. Pertama, para birokrat kebanyakan masih berorientasi kepada kekuasaan dan bukannya kepentingan publik atau pelayanan publik secara umum. Sebagian besar pejabat atau birokrat itu selama ini menempatkan dirinya dalam posisi sebagai penguasa (authorities) dan masih sangat terbatas pejabat yang menyadari perannya sebagai penyedia layanan kepada masyarakat (public servant/service provider). Budaya paternalistik seringkali juga mengakibatkan turunnya kualitas pelayanan publik. Budaya semacam ini mengakibatkan kecenderungan untuk memberikan keistimewaan kepada para elit birokrat atau orang-orang yang memiliki hubungan dengan mereka. Kedua, terdapat kesenjangan yang lebar antara apa yang diputuskan oleh pembuat kebijakan dan apa yang benar-benar dikehendaki oleh rakyat. Sistem administrasi publik dan mekanisme politik yang berlaku ternyata gagal menjembatani kepentingan elit politik dan rakyat pada umumnya. Setelah rezim orde baru turun, terdapat keinginan yang kuat dari berbagai elemen masyarakat untuk memelihara netralitas birokrasi. Namun tanpa kontrol dari sistem akuntabilitas yang cukup kuat, senantiasa terdapat kemungkinan bahwa aparat birokrasi akan merumuskan dan melaksanakan kebijakan, melaksanakan aktivitas pelayanan publik hanya berdasarkan kepentingan sempit (vested interests) dari elit atau para penguasa.

RSUD Kota Kendari merupakan salah satu sentra pelayanan kesehatan yang ada di Kota Kendari yang menjadi salah satu tempat pelayanan yang cukup menjadi pilihan masyarakat untuk memperoloh pelayanan kesehatan. Berdasarkan pengamatan yang dilakukan ditemukan beberapa masalah terkait dengan pelayanan yang ada di RSUD Kota Kendari. Antara lain, lamanya waktu tunggu antrian, keramahan petugas, terbatasnya kapasitas ruangan, kompetensi petugas rumah sakit dan masalah kejelasan biaya yang harus dikeluarkan oleh pasien yang mendapatkan pelayanan kesehatan. 
Berdasarkan uraian permasalah tersebut, maka RSUD Kota Kendari dalam upayanya untuk meningkatkan kualitas pelayanan kesehatan perlu melakukan inovasi-inovasi guna menyelesaikan keluhan dan permasalahan yang terjadi. Hal ini tentunya membutuhkan rencana dan strategi yang efektif dan efisien sehingga langkah yang diambil mampu memberikan jaminan perbaikan kualitas pelayanan. Sehingga penelitian ini bertujuan untuk mengkaji mengenai strategi peningkatan pelayanan kesehatan dengan fokus pada strategi inovasi pelayanan Kesehatan di pada Rumah Sakit Umum Daerah Kota Kendari.

\section{Metode}

Penelitian ini bersifat deskriptif kualitatif sedangkan subjek penelitian ini yaitu pihak manajemen RSUD Kota Kendari. Adapun sumber data dalam penelitian ini yaitu terdiri dari data primer dan data sekunder. Data primer diperoleh dari survei lapangan menyangkut obyek yang diteliti dan disesuaikan dengan kebutuhan. dalam hal ini pencatatan dan pengamatan langsung mengenai strategi inovasi pelayanan kesehatan pada RSUD Kota Kendari. Data primer juga diperoleh dari wawancara terhadap informan yang terdiri atas Kepala Bidang Pelayanan, Kepala Bidang Penunjang Non Medis, Kepala Bidang Keperawatan, Kepala Seksi Pelayanan Medik, Seksi Penunjang Pelayanan Medik pada RSUD Kota Kendari. Data sekunder yaitu berupa dokumen-dokumen atau literatur-literatur dari internet, surat kabar, jurnal dan lain sebagainya, pengumpulan data sekunder dilakukan dengan mengambil atau menggunakan sebagai/ seluruhnya dari sekumpulan data yang telah dicatat atau diperoleh. Metode analisis data yang digunakan adalah teknik analisis deskriptif kualitatif. Seluruh data yang diperoleh baik data primer maupun data sekunder, selanjutnya dianalisis secara kualitatif dan disajikan secara deskriptif dimulai dari pengumpulan data, reduksi data, penyajian data dan penarikan kesimpulan. 


\section{Hasil dan Pembahasan}

\section{Profil Rumah Sakit Umum Daerah Kota Kendari}

\section{a. Rumah Sakit Umum Kota Kendari}

Rumah Sakit Umum Kota Kendari atau yang sebelumnya dikenal dengan nama Rumah Sakit Abunawas merupakan salah satu unit pelayanan kesehatan milik pemerintah Kota Kendari yang secara pelayanan telah banyak mengalami perubahan dan peningkatan kualitas, hal ini terbukti dari berbagai penghargaan dan pengakuan terkait dengan kualitas pelayanan yang telah diterima baik itu dalam level lokal maupun nasional.

Berbagai penghargaan yang telah diterima oleh Rumah Sakit Umum Kota Kendari ini antara lain, penghargaan rumah sakit sayang ibu oleh Menteri Kesehatan pada tahun 2013, Predikat kepatuhan standar pelayanan publik dari OMBUDSMAN RI pada tahun 2014, dan penghargaan sebagai role model penyelenggara pelayanan publik berdasarkan hasil evaluasi terhadap $72 \mathrm{Kab} / \mathrm{Kota}$ seluruh Indonesia dengan kategori Sangat Baik pada tahun 2017.

Pada tahun 2019 Rumah Sakit Umum Daerah Kota Kendari memiliki tenaga kerja sebanyak 543 yang terdiri atas 464 tenaga kesehatan dan 79 tenaga kerja non kesehatan. Selain itu terdapat 207 tenaga kerja yang satusnya PNS pada RSUD Kota Kendari, 325 tenaga kerja non PNS atau partime, dan 11 tenaga kerja PNS namun sedang bekerja (Titipan) di RSUD korta Kendari. Adapun visi dan misi RSUD Kota Kendari sebagai berikut:

a. Visi RSUD Kota Kendari yaitu menjadi rumah sakit pilihan masyarakat

b. Misi RSUD Kota Kendari yaitu:

1. Meningkatkan Pelayanan Kesehatan dengan menciptakan pelayanan yang bermutu, cepat, tepat, serta terjangkau oleh masyarakat

2. Mendorong masyarakat untuk memanfaatkan RSUD Kota Kendari menjadi Rumah Sakit Mitra Keluarga

3. Meningkatkan SDM, Sarana dan Prasarana Medis dan Non Medis serta penunjang medis agar tercipta kondisi yang aman dan nyaman bagi petugas, pasien, dan seluarga serta masyarakat pada umumnya. 


\section{Strategi Inovasi Pelayanan Kesehatan Pada RSUD Kota Kendari}

Strategi inovasi di jelaskan merupakan suatu produk atau jasa yang baru, teknologi proses produksi yang baru, sistem struktur, dan administrasi baru atau rencana baru bagi anggota organisas. Untuk mengetahui bagaimana strategi inovasi pelayanan kesehatan pada RSUD Kota Kendari, maka langkah awal yang penting untuk dilakukan adalah dengan melakukan obsevasi terhadap program-program inovatif yang telah dibuat dan diterapkan pada RSUD Kota Kendari.

Rumah Sakit Umum Kota Kendari telah meraih berbagai penghargaan antara lain, penghargaan rumah sakit saying ibu oleh Menteri Kesehatan pada tahun 2013, Predikat kepatuhan standar pelayanan publik dari OMBUDSMAN RI pada tahun 2014, dan penghargaan sebagai role model penyelenggara pelayanan publik berdasarkan hasil evaluasi terhadap 72 Kabupaten/Kota seluruh Indonesia dengan kategori Sangat Baik pada tahun 2017.

Strategi pelayanan kesehatan yang dilakukan Rumah Sakit Umum Daerah Kota Kendari, yaitu:

a. Meningkatkan mutu pelayanan secara optimal.

b. Meningkatkan sumber daya manusia yang berorientasi pada tugas, melalui pendidikan dan pelatihan.

c. Meningkatkan sarana dan prasarana medis dan non medis sesuai kebutuhan.

d. Meningkatkan kerja sama lintas sektor dan pihak swasta melalui kerja sama yang saling bertanggung jawab dan menguntungkan.

RSUD kota Kendari sendiri mulai mengembangkan beberapa jenis program pelayanan keshatan kepada masyarakat, adapun program yang dimaksud antara lain:

Tabel 1. Program Layanan Kesehatan RSUD Kota Kendari

\begin{tabular}{|c|c|}
\hline No. & Jenis Program \\
\hline 1 & Program Gerakan Sayang Ibu \\
\hline 2 & Poliklinik dan Konseling Gizi \\
\hline 3 & Layanan SEKAR (Sistem Ketersediaan Kamar Rujukan \\
& Pasien)http://sekar-rsudkendari.com/ \\
\hline 4 & Layanan Konseling VCT (Volluntary Conselling and Testing) \\
\hline
\end{tabular}




\begin{tabular}{|c|c|}
\hline 5 & $\begin{array}{c}\text { Layanan Aduan Masyarakat Melalui Kotak Saran, Loket, Aduan } \\
\text { Telepon, SMS dan E-mail }\end{array}$ \\
\hline 6 & Pelayanan Ongkologi (Medis Kanker) \\
\hline 7 & Okupasi Terapi (Ganguan Fisik/Mental) \\
\hline
\end{tabular}

Sumber: Data Rumah Sakit Umum Daerah Kota Kendari 2019

Dari data tabel di atas terdapat tujuh program pelayanan yang saat ini diandalkan di RSUD Kota Kendari namun untuk program inovatif yang di buat oleh RSUD Kota Kendari menurut Kepala Bidang pelayanan RSUD Kota Kendari bahwa inovasi pelayanan itu merupakan program yang dimiliki rumah sakit ini yang tidak dimiliki rumah sakit lain. Inovasi pelayanan kesehatan pada RSUDKota Kendar yaitu program ketersediaan tempat tidur secara online yang dicanangkan oleh salah seorang dokter pada saat melakukan diklat Pim. Ketersedian tempat tidur pada RSUD Kota Kendari ini dapat diakses melalui HP dengan adanya aplikasi Web yang telah dibuat. Pembuatan Web ini melibatkan Program Developer yang ada di Kota kendari yang bernama Techno Studio Kendari. (Henny L.F. Mamunja, 2019)

Dari hasil wawancara tersebut bahwa inovasi pelayanan yang dibuat oleh RSUD Kota Kendari merupakan Program Inovasi SEKAR, yang mana program inovasi ini merupakan program ketersediaan kamar pasien yang dapat dicek maupun dipesan secara online. Pengembangan program ini juga melibatkan programmer professional yaitu Techno Studio. Mereka merupakan organisasi yang berbasis IT yang berdiri sejak tahun 2014.

Latar belakang inovasi SEKAR dikarenakan banyaknya komplain dari masyarakat dalam hal rawat inap dan rujukan pasien. Hal itu sejalan dengan yang disampaikan oleh salah satu pasien yang pernah dirawat di rumah sakit umum daerah Kota Kendari menyatakan bahawa "Waktu itu saya dibuat kebingungan ketika datang ke rumah sakit. Kondisinya saya harus mendapatkan tindakan lebih lanjut dan rawat inap karena mau melahirkan, namun yang terjadi adalah tidak tersedianya kamar di sini, padahal saya datang dari lokasi yang jauh. Akhirnya saya dirujuk di rumah sakit yang lain yang terdekat” (Sinta Ayu Lestari Lestari,2019). 
Hasil wawancara tersebut menunjukkan bahwa kepastian ketersediaan kamar pasien sangat penting dan perlu menjadi perhatian khusus dalam pelayanan di rumah sakit.

Pada saat melakukan wawancara dengan Kepala Bidang Penunjang Non Medis RSUD Kota Kendari, menjelaskan bahwa program invovasi pada RSUD Kota Kendari saat ini adalah program informasi ketersedian kamar secara online (SEKAR). Program inovasi SEKAR dibuat akibat tidak teraksesnya informasi ketersediaan ruang rawat inap yang menyebabkan tidak adanya kepastian layanan sehingga mengakibatkan keterlambatan dalam pelayanan yang dapat berakibat pasien meninggal sebelum diberikan pelayanan.(Sumarni, 2019)

Berdasakan hasil tersebut bahwa program inovasi SEKAR merupakan pengolaan sisem informasi pelayanan kesehatan pada RSUD Kota Kendari. Sistem Informasi Pelayanan Rujukan yang dilaksanakan di RSUD Kota Kendari yang awalnya disajikan secara manual yang menyebakan tidak teraksesnya informasi ketersediaan ruangan secara terbuka atau Online bagi pengguna layanan, baik Puskesmas maupun masyarakat secara umum sehingga sering terjadi komplain.

Selain itu akibat tidak teraksesnya informasi ketersediaan ruang rawat inap menyebabkan tidak adanya kepastian layanan sehingga mengakibatkan keterlambatan dalam pelayanan yang dapat berakibat pasien meninggal sebelum diberikan pelayanan maka inovasi dilakukan dengan rancangan Sistim Informasi secara online mengenai Ketersediaan Ruangan Rawat Inap Bagi PasienRujukan dari Puskesmas yakni:

1. Menginventarisasi jumlah Ruang Rawat Inap dan Jumlah Kamar yang dapat dimanfaatkan untuk menerima pasien rujukan

2. Merancang Sistem Informasi Ruangan berbasis Aplikasi bagi pasien Rujukan yang akan dilaksanakan oleh Tenaga ahli.

3. Melakukan bimbingan teknis bagi petugas Sentral Opname serta petugas terkait lainnya.

4. Menginformasikan kepada Seluruh Puskesmas Se - kota Kendari tentang kesiapan Sistim Informasi Ketersediaan Ruang Rawat Inap bagi Pasien rujukan. 
5. Operasionalisasi.

6. Mengontrol Sistem Informasi tersebut secara berkelanjutan.

Strategi inovasi Sistem Ketersediaan Kamar Rujukan Pasien (SEKAR) yang merupakan perbaikan pelayanan keshatan pada RSUD Kota Kendari dengan mengoptimalisasikan pelayanan melalui sistim informasi ketersedian kamar rawat inapyang awalnya disajikan secara manual, kini dapat di ketahui secara online. Sistem informasi ini dapat di gunakan untuk pengguna layanan kesehatan pada setiap puskesmas yang ada di Kota Kendari maupun masyarakat umum.

Hal ini searah dengan tipologi inovasi sektor publik yang dikemukakan oleh Halvorsen (2005) yang merupakan cara untuk menentukan kategori sebuah inovasi sebagai a new or improved service (pelayanan baru atau pelayanan yang diperbaiki) dalam hal ini misalnya, kesehatan di rumah; process innovation (inovasi proses), misalnya perubahan dalam proses penyediaan pelayanan atau produk; system innovation (inovasi sistem) yaitu sistem baru atau suatu perubahan mendasar dari sistem yang ada dengan mendirikan organisasi baru atau bentuk baru kerjasama dan interaksi.

\section{a. A New or Improved Service}

A new or improved service dalam artian pelayanan baru atau pelayanan yang diperbaiki yang adalah program inovasi yang di buat merupakan program pelayanan yang sudah ada dan di perbaiki baik secara adminstrasi maupun cara pelaksanaannya sudah sesuai dengan prosedur yang telah dibuat sebelumnya

Hasil wawancara dengan Kepala Bidang Keperawatan RSUD Kota Kendari yang menjelaskan bahwa "inovasi SEKAR di buat dengan tujuan meminimalisir keluhan masyarakat tentang ketidakpastian ketersediaan kamar. Informasi ketersedian kamar rawat inap sekarang sudah dapat di cek secara langsung melului aplikasi web. Sistem ini dibuat karena sebelumnya banyak kasus pasien dalam maupun luar kota kendari yang ingin berobat di rumah sakit ini, namun saat tiba disini ruangan rawat inap full” ( Syarif, 2019).

Berdasarkan wawancara tersebut bahwa inovasi SEKAR yang merupakan sistem informasi kertesedian kamar rawat inap pada RSUD Kota Kendari sekarang dapat di ketahui dengan mudah. Sistem informasi berbasis online memudahakan 
puskesmas yang ada di kota kendari maupun masyarakat secara umum bisa mengetahui ketersedian kamar secara langsung. Program inovasi ini di buat karena banyak kasus pasien yang datang ke RSUD Kota Kendari tidak dilayani dikarenakan kamar rawat inap yang telah penuh.

Lebih lanjut Kepala Bidang Penunjang Non Medis RSUD Kota Kendari yang menjelasakan bahwa "sering terjadi komplain mengenai ketersediaan kamar, untuk itu kami melakukan optimalisasi pelayanan melalui sistim informasi rujukan berbasis aplikasi Web mengenai ketersediaan ruang rawat inap agar seluruh Puskesmas yang ada di kota Kendari dapat memanfaatkan informasi ini untuk memberikan pelayanan rujukan yang maksimal kepada masyarakat Kota Kendari bahkan masyarakat luar daerah Kota Kendari” ( Sumarni,2019)

Berdasarkan wawancara tersebut bahawa ketersedian kamar rawat inap yang dapat di cek secara online merupakan optimalisasi dari informasi layanan kesehatan pada RSUD Kota Kendari. Dengan adanya inovasi ini diharapkan masyarakat yang ingin dirawat pada RSUD Kota Kendari dapat mengetahui terlebih dahulu ketersedian kamar inap, sehingga pasien dapat mencari alternatif rumah sakit lain untuk natinya bisa langsung mendapatkan pleyanan atau tindakan medis.

Program inovasi SEKAR merupakan pelayanan baru atau pelayanan yang diperbaiki dengan upaya optimalisasi pelayanan melalui sistem informasi rujukan berbasis aplikasi web mengenai ketersediaan ruang rawat inap agar seluruh Puskesmas yang ada di Kota Kendari dapat memanfaatkan informasi ini untuk memberikan pelayanan rujukan yang maksimal kepada masyarakat Kota Kendari khususnya bahkan masyarakat Sulawesi Tenggara pada umumnya.Dengan tujuan meminimalisir keluhan masyarakat tentang ketidakpastian ketersediaan kamar. Dengan adanya informasi ini, penanganan lebih cepat dilakukan sehingga dapat mencegah kematian karena keterlambatan akses pelayanan.

\section{b. Process Innovation}

Proses inovasi merupakan sebuah sistem yang berkaitan dengan penyediaan pelayanan kearah yang lebih baik atau sesuai dengan kebutuhan. Proses inovasi melihat bagaimana proses pembuatan yang berorientasi pada perbaikan pelayanan. 
Hasil wawanacara dengan Kepala Bidang Pelayanan RSUD Kota Kendari) yang menjelaskan bahwa "inovasi SEKAR pada RSUD Kota Kendari adalah dapat membantu puskesmas-puskesmas yang ada di Kota Kendari dan masyarakat secara umum dalam mendapatkan informasi ketersedianan kamar rawat inap pada rrumah sakit ini. Penguuna layanan dapat mengecek secara langsung ketersedian kamar rawat inap, pengguna layanan juga dapat melakukan pemesan kamar melalui website SEKAR.” (Henny LF. Mamuaja, 2019)

Melalui keberadaan program ini ini, ada jaminan kepastian layanan ruang rawat inap bagi pasien rujukan sehingga dapat meminimalisir keluhan masyarakat dan penanganan lebih cepat dilakukan sehingga dapat mencegah kematian karena keterlambatan akses Pelayanan.

Selain itu saat Seksi Penunjang Pelayanan Medik yang menjelaskan bahwa selain informasi ketersediaan kamar rawat inap pada rumah sakit, pengguna layanan dapat melakukan booking atau pemesnan kamar. Terdapat keterangan fasilitas yang ada pada setiap kamar. Untuk itu pengguna layanan dapat memilih sendiri ruangan beserta fasilitas yang nantinya digunakan pada kamar yang dipesan. (Rosita, 2019). Berdasarkan hasil tersebut bahwa inovasi ketersediaan kamar rawat inapa bagi pasien adalah program inovasi pelayanan yang dibuat untuk mengoptimalisasikan informasi pelayanan ketersediaan kamar rawat inap.

\section{c. System Innovation}

Inovasi sistem merupakan sebuah sistem baru atau sebuah perubahan mendasar dari sistem yang telah ada sebelumnya dengan mendirikan sebuah organisasi baru atau kerja sama instansi-instansi terkait sebagai wujud penerapan pengembangannya.kegiatan ini dilakukan untuk mengembangkan inovasi agar dapat dirasakan perbedaan yang telah dirasakan dengan hadirnya inovasi tersebut. Karean sejatinya inovasi akan membuat perubahan-perubahan kearah yang lebih baik dan memperlihatkan kebermanfaatannya.

Hasil wawancara dengan Kepala Bidang Keperawatan RSUD Kota Kendari mengungkapkan bahwa "kedepannya inovasi SEKAR tidak lagi disajikan dalam web, melainkan akan dibuatkan aplikasi yang nantinya dapat di download 
pada play store. Melalui gadged atau HP android diakses dengan sistem online kita bisa langsung mengetahui ketersedian kamar pada saat itu juga." (Syarif, 2019). Berdasarkan hasil wawancara tersebut bahwa sistem informasi ketersediaan kamar rawat inap kedepannya sudah tidak melalui website lagi, melainkan informasi ketersedian kamar rawat inap sudah berbasis aplikasi yang dapat didownload dan lebih mudah diakses melalui smart phone.

Selain itu bagian Seksi Penunjang Pelayanan Medik menjelaskan bahwa sistim informasi pelayanan rujukan yang dilaksanakan di RSUD Kota Kendari awalnya disajikan secara manual. Hal tersebut menyebakan tidak teraksesnya informasi ketersediaan ruangan secara terbuka atau online bagi pengguna layanan. melalui inovasi SEKAR dengan sistim informasi berbasis aplikasi Web mengenai ketersediaan ruang rawat inap dapat mengatasi maslah mengenai informasi layanan ketersedian kamar rawat inap di RSUD Kota Kendari( Rosita, 2019)

Pada awalnya untuk informasi ketersedian kamar rawat inap bagi pasien rujukan sulit untuk mengetahui ketersediaan kamar rawat inap pada RSUD Kota Kendari. Hal ini dikarenakan informasi yang dapat diperoleh hanya ketika pengguna layanan datang langsung ke rumah sakit. Namun saat ini informasi ketersedian kamar rawat inap dapat diketahui secara langsung melalui sistem informasi ketersedian kamar inap pasien melalui web SEKAR. Dengan mengakses web tersebut pengguna layanan tidak hanya dapat mengetahui mengenai ketersedian kamar, melainkan pengguna layanan dapat melakukan pemesanan (booking) kamar rawat inap.

Berdasarkan hasil tersebut bahwa inovasi SEKAR dapat dikategotikan sebagai System Innovation menurut Halvorsen (2005) yang merupakan sebuah sistem baru atau sebuah perubahan mendasar dari sistem yang telah ada sebelumnya. Inovasi dapat dirasakan perbedaan yang telah dirasakan dengan hadirnya inovasi tersebut. Namun pada dasarnya inovasi ini dijalankan tanpa melalui mitra atau kerja sama dengan pihak lain dalam pengaplikasian inovasi ini. Melalui program ini puskesmas-puskesmas yang ada di Kota Kendari dapat membuat rujukan dengan berpatokan pada ketersedian kamar pada RSUD Kota Kendari. 


\section{Proses Implementasi dan Manfaat Inovasi Pelayanan Kesehatan Pada Rumah Sakit Umum Daerah Kota Kendari}

Program SEKAR merupakan Optimalisasi pengelolaan informasi pelayanan kesehatan melalui Sistim Informasi Rujukan Berbasis Aplikasi Webmengenai ketersediaan ruang rawat inap agar seluruh Puskesmas yang ada di Kota Kendari dapat memanfaatkan Informasi ini untuk memberikan pelayanan rujukan yang maksimal kepada masyarakat Kota Kendari khususnya, bahkan masyarakat Sulawesi Tenggara pada umumnya dengan tujuan meminimalisir keluhan masyarakat tentang ketidakpastian ketersediaan kamar. Dengan adanya informasi ini, penanganan lebih cepat dilakukan sehingga dapat mencegah kematian karena keterlambatan akses Pelayanan.

Kepala Bidang Keperawatan RSUD Kota Kendari) mengungkapkan bahwa "program SEKAR merupakan Sistim Informasi Rujukan Berbasis Aplikasi Web mengenai ketersediaan Ruang Rawat Inap. Masyarakat yang ingin memesan kamar inap dapat melihat langsung profil ruangan maupun faslitas yang terdapat pada ruang inap tersebut. Selain itu kita masyarkat dapat mengetahui profil dokter yang nantinya akan menagani pasien yang akan di rawat pada kamar inap yang telah di pesan". (Syarif. B, 2019)

Berdasarkan wawancara tersebut bahwa program SEKAR yang merupakan sistem informasi rujukan berbasis aplikasi web yang bertujuan untuk memberikan informasi kepada masyarakat mengenai ketersediaan kamar inap bagi pasien yang akan di rujuk ke RSUD Kota Kendari. Hal ini dimaksudkan agar masyarakat dapat langsung mendapat layanan serta mencegah adanya pasien rujukan yang tidak dapat memperoleh kamar inap pada saat di rujuk ke RSUD Kota Kendari.

Lebih lanjut Kepala Bidang Pelayanan RSUD Kota Kendari, menjelaskan bahwa pada program inovasi Sekar berbasis aplikasi web terdapat menu pada web yang dapat mebantu masyarakat untuk mengetahui ketersedian kamar pada RSUD Kota Kendari. Selain menu ketersediaan kamar terdapat beberapa menu lain yang dapat di lihat oleh masyarakat seperti halnya menu fasilitas kamar yang akan dipesan, dan menu data dokter. (Henny LF. Mamuaja, 2019). 
Selain itu wawancara dengan Kepala Bidang Penunjang Non Medis RSUD Kota Kendari menjelaskan bahwa sejak diluncurkan pada November 2016, program SEKAR belum termanfaatkan dengan baik oleh masyarakat. Permaslahannya adalah publikasi dan sosialisasi program SEKAR ini belum maksiamal, sehingga masyarakat kebanyakan belum mengetahui bahwa ada program yang sangat bermanfaat dan membantu mereka dalam mendapatkan layanan pemesanan kamar. Sarana dalam pengaplikasian program ini masi menjadi kendala di karenakan operator dan komputer masih terbatas. Selain itu saat ini bagi masyarakat yang telah melakukan pemesanan kamar, masyarakat harus mengonfirmasi kembali secara langsung ke pihak RSUD Kota Kendari selambatnya 3 jam setelah pemesanan. Hal ini sesuai waktu yang telah di tentukan pada saat melakukan pemesanan atau booking kamar yang telah dilakukan. (Sumarni, 2019)

Inovasi pelayanan Sistem Ketersediaan Kamar Rujukan Pasien (SEKAR) secara online masi melangalami banyak kendala. Namun kedepannya manajemen RSUD Kota Kendari akan membenahi program ini sehingga masyarakat dapat terbantu dengan adanya program ini. Bentuk layanan pada saat mengases SEKAR pada halaman wala web (tampilan front-end) kita dapat melihat langsung ketersedian kamar pada pada tabel ketersedian kamar RSUD Kota Kendari.

Kemudian terdapat detail menu gedung yang dapat pilihan edit untuk memilih fasilitas dan dokter yang akan di pilih digunakan. Menu ini disediakan guna masyarakat dapat memilih fasilitas yang sesuai dengan keinginan serta dapat menjamin kenyamanan pasien yang dirawat.

\section{Gambar 1. Tampilan Layanan SEKAR}

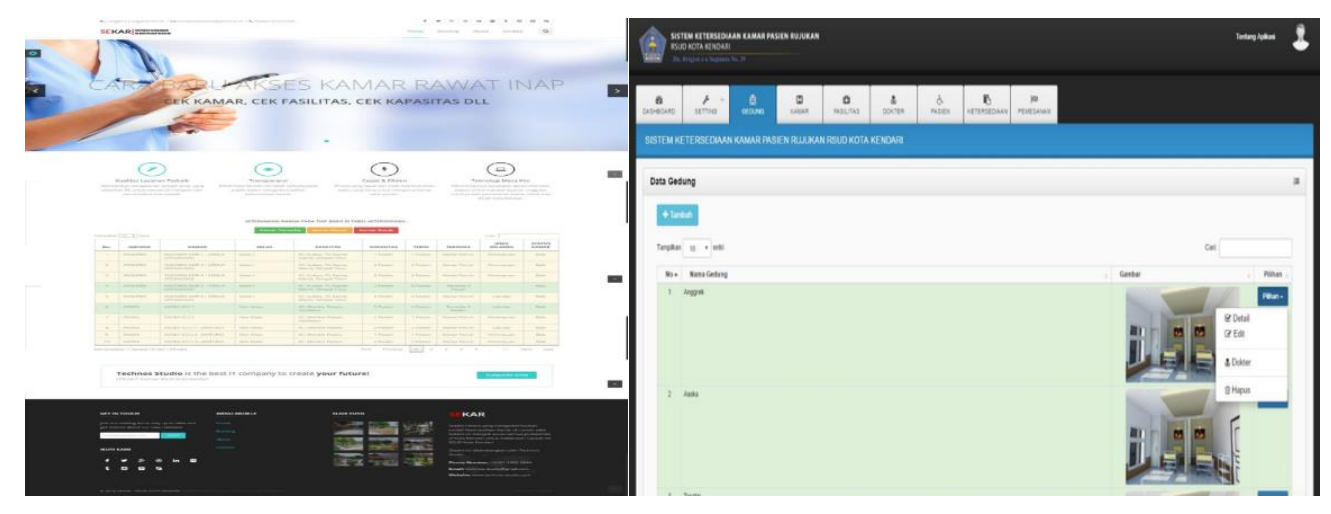

Sumber: Data Sekunder RSUD Kota Kendari, 2019 
Ketika masyarakat telah menentukan kamar atau gedung yang ingin dipesan, fasilitas yang terdapat pada kamar inap, serta dokter yang dipilih, kemudian masyarkat dapat langsung memilih pilihan booking pada halaman booking kamar yang telah tersedia.

Dari beberapa gambar tampilan inovasi Sistem Ketersediaan Kamar Rujukan Pasien (SEKAR) yang merupakan Sistem Informasi ketersediaan Ruangan Rawat Inap/kamar Bagi Pasien Rujukan dari Puskesmas terdapat menu lain yang dapat menjadi pilihan masyarakat ketika melakukan pemesanan (Booking) kamar inap.

\section{Faktor Penghambat Inovasi Pelayanan Kesehatan pada Rumah Sakit Umum Daerah Kota Kendari}

Program SEKAR yang merupakan penglolaan informasi pelayanan secara online mengenai ketersedian kamar rawat inap bagi pasien. Sejak tahun 2016 pada saat di luncurkan sampai sekarang terdapat berbagai macam kendala dalam pengimplemntasinnya. Faktor penghambat program inivasi pada RSUD Kota Kendari adalah sebagai berikut:

\section{a. Anggaran Jangka Pendek dan Perencanaan}

Pengembangan inovasi baik dalam skala organisasi maupun pada pasyarkat umum haruslah direncanakan dengan baik bukan hanya dalam perpektif tahunan, namun juga perspektif jangka menengah dan jangka panjang. Sejak diluncurkan tahun 2016 program SEKAR yang merupakan pengelolaan sistem informasi ketersediaan ruang rawat inap. Namun sampai saat ini masih terdapat beberapa kendala pada implementasinya. Anggaran yang terbatas, sistem perencanaan program masih terhambat menyebabkan program ini belum terlaksana dengan baik. Penyebanya kelengkapan sarana dan prasarana peralatan dan software penujang dalam pengaplikasian program ini masih terbatas.

Ketersedian sarana komputer dan sistem jaringan pada setiap gedung perawatan masih terbatas. Tentunya ini dikarenakan anggaran untuk penyedian peralantan program ini masi belum mencukupi. Ditinjau sejak peluncuran pertama program ini pada tahun 2016 sampai sekarang peralatan komputer dan sistem 
jaringan pada setiap gedung perawatan masih terbatas, artinya selama 3 tahun ini belum ada penyelesain kendala tersebut. (Syarif. B, 2019)

Tidak dipungkiri sistem SEKAR masi terdapat kekurangan. Dilihat dari waktu booking atau pemesanan kamar yang berselang 3 jam pasien harus tiba di rumah sakit. Hal ini menjadi kendala dikarenakan pasien yang dirawat di RSUD Kota Kendari tidak hanya dari Kota Kendari saja melainkan pasien dari daerah lain juga, sementara itu bagaiana dengan pasien dari luar Kota Kendari yang memerlukan waktu tempuh lebih dari 3 jam untuk sampai di RSUD Kota Kendari. Namun disisi lain akan ada perbaikan sistem yang awalnya bebasis website di rencanakan kedepannya suda menggunakan aplikasi yang dapat diinstal pada smart phone. (Sumarni, 2019 )

Dari hasil tersebut bahwa anggaran yang masi terbatas belum dapat memenuhi ketesedian ketersedian peralantan komputer dan sistem jaringan pada setiap gedung perawatan. Perbaikan awaktu pemesanan kamar perlu dilakukan mengingat pasien yang ingin mendapat pelayanan kesehatan pada RSUD Kota Kendari tidak hanya berasal dari dalam Kota Kendari, melainkan terdapat pasien yang berasal dari luar Kota Kendari. Perubahan sistem informasi yang awalnya melalui website akan diubah menjadi sistem informasi berbasis aplikasi SEKAR yang dapat di instal pada smart phone.

\section{b. Sosialisasi}

Pengenanalan program baru mengenai pelayanan terhadap masyarakat menjadi faktor penting guna mamastikan program yang berjalan dapat digunakan atau termanfaatkan oleh masyarakat. Pentingnya sosialisasi terhadap program baru pelayanan di masyarkat ini perlu dijalankan, namun pada kondisinya program sistem ketersedian kamar pasien rujukan (SEKAR) masih belum termanfaatkan di masyarakat. Hal ini dikarenakan masyarakat masih banyak yang belum mengetahui program ini. Kondisi tersebut dibuktikan dengan pendapat pengguna layanan atas yang menyatakan bahwa "Sejauh ini saya belum pernah menggunakan pemesanan kamar dengan cara seperti itu (menggunakan SEKAR),masih mendaftar manual di bagian administrasi rumah sakit”.( Ayu Irty Qalby, 2019). Pendapat tersebut telah 
membenarkan bahwa sosialisasi mengenai inovasi yang dilakukan oleh pihak rumah sakit belum sampai ke lapisan masyarakat hingga ke bawah.

Dari hasil wawancara juga bahwa yang masih menjadi kendala pada program SEKAR ini adalah masih kurangnya pengenalan program kepada masyarakat. Kemudian kurangnya sarana penunjang berupa komputer dalam pengaplikasian program ini. Data penggunaan ruang rawat inap maupun yang kamar inap masi kosong menjadi kendala dikarenakan pada setiap gedung perawatan yang harusnya dapat memperbaharui kamar yang telah terisi maupun kamar yang kosong. (Syarif. B, 2019)

Menurut Kepala Bidang Pelayanan RSUD Kota Kendari masyarakat belum banyak yang tau mengenai informasi ini sosialisasi maupun publikasi program belum maksimal di karenakan sistem SEKAR yang masi banyak terdapat kendala di dalamnya. Data kondisi ruangan yang terisi dan belum terisi masih belum jelas. (Henny LF. Mamuaja, 2019).

Kendala mengenai sitem SEKAR ini dijelaskan juga oleh Seksi Penunjang Pelayanan Medik yang menjelaskan bahwa pada saat melakukan booking kamar inap masyarakat memiliki batas waktu 3 jam untuk melakukan konfirmasi langsung ke pada pihak rumah sakit dengan kata lain pasien yang di rujuk harus tiba di RSUD Kota Kendari sebelum waktu booking habis. Jika waktu booking kamar telah habis maka, kamar yang telah dibooking secara otomatis terbatalkan. (Rosita,2019)

Inovasi SEKAR yang merupakan sistem informasi ketersediaan ruangan rawat inap atau kamar bagi pasien yang diluncurkan sejak tahun 2016 belum berjalan secara maksimal. Masi terdapat beberapa kendala dalam pengaplikasiannya. Kendala tersebut meliputi kurangnya ketersedian sarana penunjang pengoperasian, waktu booking kamar yang terbatas dan sistem aplikasi yang masih bebasis web. (Sumarni,2019)

Berdasarkan hasil tersebut bahwa sejak diluncurkan pada tahun 2016 program SEKAR yang merupakan pengelolaan sistem informasi ketersediaan ruang rawat inap agar seluruh Puskesmas yang ada di Kota Kendari dapat memanfaatkan informasi ini untuk memberikan pelayanan rujukan yang maksimal kepada masyarakat Kota Kendari khususnya bahkan masyarakat Sulawesi Tenggara pada 
umumnya sampai saat ini masih terdapat beberapa kendala dalam penerapannya. Pada dasarnya dengan tujuan meminimalisir keluhan masyarakat tentang ketidakpastian ketersediaan kamar pada RSUD Kota Kendari, dengan adanya kenda-kendal tersebut bahwa informasi ketersedian kamar inap menjadi tidak akurat. Program ini masih belum termanfaatkan dengan baik di kalangan masyarakat yang disebabkan ketidak tahuan masyarakan tentang program ini.

\section{Kesimpulan}

Hasil penelitian ini dapat disimpulkan bahwa bahwa strategi inovasi pelayanan kesehatan pada RSUD Kota Kendari berupa inovasi sistem informasi rujukan berbasis aplikasi web mengenai ketersediaan Ruang Rawat Inap atau yang dikenal dengan program inovasi Sistem Ketersediaan Kamar Rujukan Pasien (SEKAR) dengan sistem informasi layanan ini seluruh Puskesmas yang ada di Kota Kendari dapat memanfaatkan Informasi ini untuk memberikan pelayanan rujukan yang maksimal kepada masyarakat Kota Kendari khususnya bahkan masyarakat Sulawesi Tenggara pada umumnya dengan tujuan meminimalisir keluhan masyarakat tentang ketidakpastian ketersediaan kamar. Dengan adanya informasi ini, penanganan lebih cepat dilakukan sehingga dapat mencegah kematian karena keterlambatan akses pelayanan. Dalam penerapan inovasi ini pihak manajemen RSUD Kota Kendari masih menghadapi beberapa kendala diantaranya kurangnya sosialisasi dan publikasi mengenai layanan kesehatan ini, pemutakhiran data pasien pada setiap kamar rawat menjadi kendala. Selain itu anggaran sebagai pemenuhan ketersedian sarana penunjang seperti komputer masih terbatas

\section{Referensi}

Albury, David. (2003). Innovation in the Public Sector. Discussion paper. The Mall. London

Bungin, Penelitian Kualitatif: Komunikasi, Ekonomi, Kebijakan Publik, dan Ilmu Sosial Lainnya. Jakarta: Kencana Prenada. (2007). 
Denhardt, Janet and Robert Denhardt. (2000). The New Public Service: Serving Rather than Steering. Journal Public Administration Review. November/December (2000), Vol. 60, No. 6

Depdagri dan LAN, (2007), Modul 1 Paradigma Kebijakan Pelayanan Publik di Era Otonomi Daerah, Diklat Teknis Pelayanan Publik, Akuntabilitas, dan Pengelolaan Mutu. Jakarta: Depdagri

Dwiyanto, Agus, (2010), Manajemen Pelayanan Publik: Peduli, Inklusif, dan Kolaboratif, Yogyakarta: Gadjah Mada University Press.

Halvorsen, Thomas, et al (2005). On the Differences between public and private sector innovations. Publin Report. Oslo.

Hardiyansayah. (2011). Kualitas Pelayanan Publik, Konsep, Dimensi, Indikator dan Implementasinya. Yogyakarta: Gava media.

Kumorotomo, Wahyudi. (2013). Akuntabilitas Birokrasi Publik. Yogyakarta: Pustaka Pelajar dan MAP UGM.

Manufandu, J. Septer. (2009). Praktek Pelayanan Publik di Suku Pedalam di Daerah Pedalaman Provinsi Papua Barat. Materi Seminar.

Moenir. (2010). Manajemen Pelayanan Umum di Indonesia. Jakarta: Bumi Aksara Napitupulu, Paimin, (2007), Menakar Urgensi Otonomi Daerah, Solusi atas Ancaman Disintegrasi, Bandung: Alumni.

Ombudsman. (2016). Data Penyelesaian Laporan Masyarakat tahun (2016)

Presiden Republik Indonesia. (2009). Undang-Undang Nomor 25 Tahun 2009 tentang Pelayanan Publik. Diakses 26 Mei, 2019, pada Jaringan Dokumentasi dan Informasi Hukum (JDIH) Badan Pemeriksa Keuangan (BPK) RI website: https://peraturan.bpk.go.id/Home/Details/38748/uu-no-25-tahun-2009

Presiden Republik Indonesia.(2014). Undang-undang No. 23 Tahun 2014 Tentang Pemerintahan Daerah. Diakses 26 Mei, 2019, pada Jaringan Dokumentasi dan Informasi Hukum (JDIH) Badan Pemeriksa Keuangan (BPK) RI website: https://peraturan.bpk.go.id/Home/Details/38685/uu-no-23-tahun-2014 
Rasyid, M. Ryaas. (1998). Kajian Awal Birokrasi Pemerintahan dan Politik Orde Baru. Jakarta: Yarsif Watampone

Ratminto dan Winarsih, Atik. (2005). Manajemen Pelayanan. Yogyakarta: Pustaka Pelajar.

Rogers, E.M., (2003). Diffusion of Innovations 5 edition, Free Press. New York. Sedarmayanti, (2000). Tata Kerja Dan Produktivitas Kerja (Suatu Tinjuan dari Apek Ergonom atau Kaitan Antara Manusia Dengan Lingkungan Kerja). Bandung:CV.Mandur Maju.

Siagian, Sondang P. (2001). Kerangka Dasar Ilmu Administrasi. Jakarta: Rineka Cipta.

Sinambela, Lijan P. (2008). Reformasi Pelayanan Publik. Jakarta: Bumi Aksara

Straus, Anselm \& Corbin Juliet, Dasar-Dasar Penelitian Kualitatif, Yogyakarta: Pustaka Pelajar, (2003).

Tajibu, M.J., \& Syawal Zakaria, "Desain Penelitian Kualitatif” dalam Desain Penelitian: Pendekatan Kualitatif, Malang: Insan Muamalah Publisher, (2012).

Thoha, Miftah. (2008). Birokrasi Pemerintahan Indonesia di Era Reformasi. Jakarta: Kencana Prenada Media Group.

Thoha, Miftah. (1991). Perspektif perilaku birokrasi (Dimensi-Dimensi Prima Ilmu Tjiptono, Fandy. (2000). Manajemen Jasa. Yogyakarta: Andi.

Tyran, Jean-Robert and Rupert Sausgruber., ( 2003). The Diffusion of Policy Innovation: An Experimental Investigation. Discussion Paper no. (2003)-14. Department of Economics, Universität St.Gallen.

\section{Wawancara}

Lestari, Sinta Ayu. (2019). Kendari. 25 Mei 2019

Mamunja, Henny L.F. (2019). RSUD Kota Kendari. 25 Mei 2019

Rosita. (2019). RSUD Kota Kendari. 26 Mei 2019

Sumarni. (2019). RSUD Kota Kendari. 25 Mei 2019

Syarif B. (2019). RSUD Kota Kendari. 26 Mei 2019

Qalby, Ayu Irty. (2019). RSUD Kota Kendari. 26 Mei 2019 